\title{
NGT CARGO - CONCEPT FOR A HIGH-SPEED FREIGHT TRAIN IN EUROPE
}

\author{
TILO SCHUMANN, MICHAEL MOENSTERS, CHRISTIAN MEIRICH \& BAERBEL JAEGER \\ German Aerospace Center (DLR), Institute of Transportation Systems (TS), Braunschweig, Germany
}

\begin{abstract}
The Next Generation Train (NGT) is a research project of the German Aerospace Center (DLR). Within this project we develop concepts for a new high-speed train, a regional train and a fast freight train. For the fast freight train concept, called NGT CARGO, we analyzed an exemplary European corridor between Madrid and Bucharest. The train uses high-speed lines in Spain, France and Germany and then follows the Danube corridor railway lines through Austria, Hungary and Romania. A scenario was set up to shift adequate (high-value, expeditious goods) from truck transport to this high-speed rail system. Knowing the volume of goods from the traffic forecast 2030 from the German Ministry of Transport (BMVI) two rail-logistic approaches have been compared: a single wagon system with shunting and a line train system where the goods are transshipped automatically between the trains in terminals. The goods of course have to be treatable in an automatic way, e.g. euro pallets with maximum loading volume and fastened goods. The departure frequency of the trains has to be high in order to reach a high average transport speed. That's why the volume of goods per train is low, which makes a single wagon system inefficient. There complete wagons have to depart for instance daily notwithstanding their load factor. Furthermore, a timetable analysis has been done for the German and partly the French section of the route to evaluate the feasibility of integrating a high-speed cargo train into the current and future traffic flow on conventional and high-speed lines. Passenger trains keep their higher priority (even local trains). Only conventional freight trains are ranked lower than the NGT CARGO. The analysis shows, that a train path under real conditions is slightly slower than the ideal trajectory, but this has not a deep impact to the average transport speed.

Keywords: next generation train, freight rail, cargo, timetable, transport planning, Europe, highspeed, operational concept, single wagon load, line train.
\end{abstract}

\section{INTRODUCTION}

The NGT Cargo concept envisages the use of a passenger-like high-speed train for transporting adequate goods in a fast and safe way on an economical base. The idea is to establish a fast freight transport systems which is able to replace air cargo on dedicated relations and helps to shift freight from road traffic to the rail. The concept was created in the following steps:

- $\quad$ First adequate cargo types are chosen, for which shippers are willing to pay for a fast transport. There has to be a database in which the cargo types could be distinguished to do further calculations.

- The second step is to select a reference line for creating the operational concept with a specific application. The selection criteria depend on a big freight volume of the defined high-value cargo and a balanced traffic in both directions.

- The third step is the definition of base parameters for the train concept which is necessary to calculate transport times.

- The fourth step is the definition of the corridor and specific rail lines, on which the new train will operate. The traversed areas are also served by the train. 
- With the fifth step detailed origin - destination freight volume data is analysed and serves as an input for the operational scenarios. For example, the amount of freight in one traffic cell is a consequence for selecting hub stations.

- The sixth step is the derivation of operational concepts which depend on the logistics concept. From freight volumes the number of wagons is calculated and based on this the formation of trains take places. The operational concepts differ basically between a system where wagons are going from the origin to the destination with shunting processes in between and a system where the goods are transhipped between different trains (similar to passenger traffic).

- The seventh and eighth step is the creation of a timetable scheme and the integration into to the timetable.

- Finally, the key performance indicators of the concepts are calculated and used for evaluation (e.g. average transport speed, amount of vehicles, energy consumption).

\section{NGT CARGO PROJECT}

The German Aerospace Center (DLR) develops a concept called Next Generation Train Cargo (NGT CARGO) [1]. The aim of the concept is to increase the share of freight rail in Europe. As the transport of small, urgent consignments in particular will increase sharply in the future, the concept focuses on fast and reliable freight transport. It is characterized by a high degree of automation, intelligent shunting and a higher speed compared to conventional freight trains.

To better understand the idea of the NGT CARGO, we need to look at today's European freight rail market. On the one, hand block trains are very common, on the other hand single wagon load transport is still to be found frequently.

Block trains are not shunted, because they form a complete unit consisting of uniform wagons. As the name already says block trains transport a large, uniform volume of freight with a large number of wagons. Furthermore, block trains often only transport goods on fixed connections from start to end with no intermediate stops for loading, unloading or shunting.

Until today single wagonload transport has been a very time-consuming process with complex operating procedures. To transport the goods from start to destination, several steps are necessary, e.g. separation, collection and assembly of wagons. A multitude of manual coupling processes lead to long downtimes of the individual wagons. Therefore, the transport speed is very low compared to block trains [2].

To increase the share of single wagonload transport, the NGT CARGO concepts takes a new approach with many improvements. The NGT CARGO freight wagons have their own propulsion based on electric motors and a battery. Due to its power the individual wagons can maneuver independently and shunting locomotives or overhead lines are no longer required. In addition, the individual wagons can automatically and autonomously drive the last few kilometers to the respective customer (cp. to locomotives with last-mile module) (see Fig. 1) [3].

For this purpose, each individual wagon is equipped with the appropriate sensors. The wagons can also be driven directly into ports, transhipment stations or specialized logistics terminals, where they are loaded or unloaded automatically (see Fig. 2). With regard to the handling process, the wagons are designed for loading air cargo containers. Due to this, they will be equipped with a roller floor. The payload of each wagon will be maximally 35 tons, divided into two double-deck cargo sections, which is each up to $1.5 \mathrm{~m}$ high. The NGT CARGO will be able to cope with all power and train protection systems in the planned area of operation. 


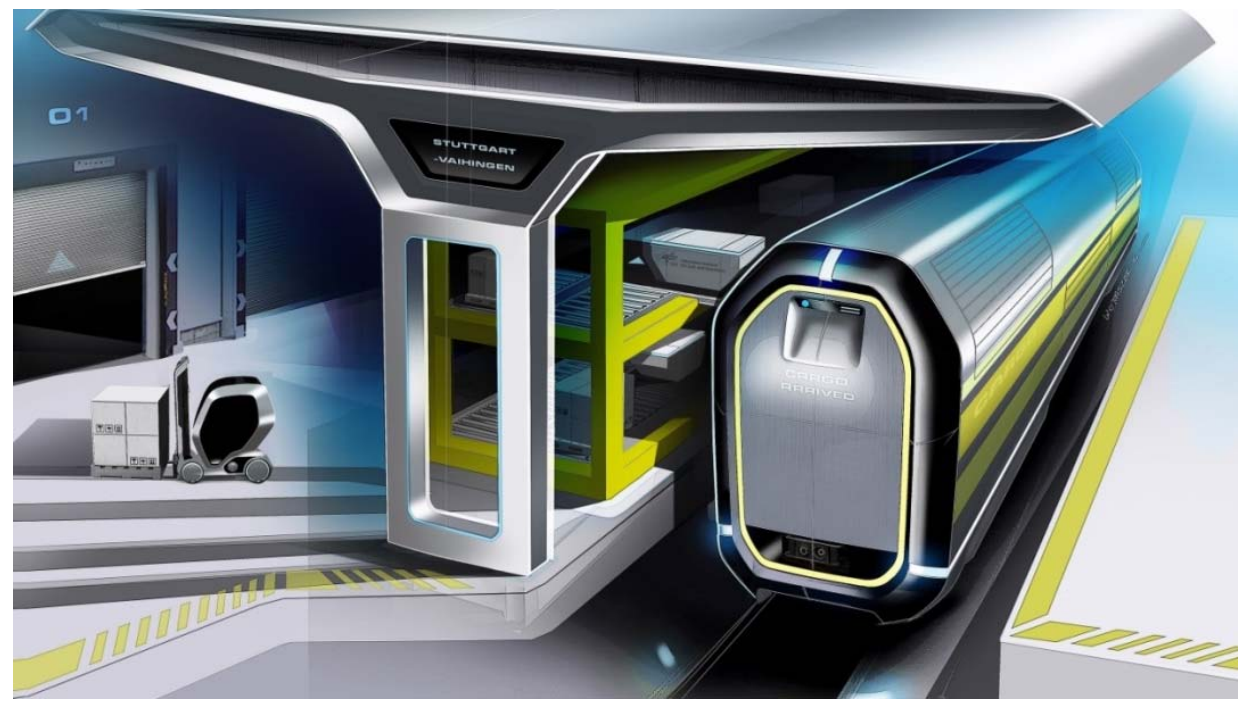

Figure 1: NGT CARGO last mile terminal. (Source: DLR.)

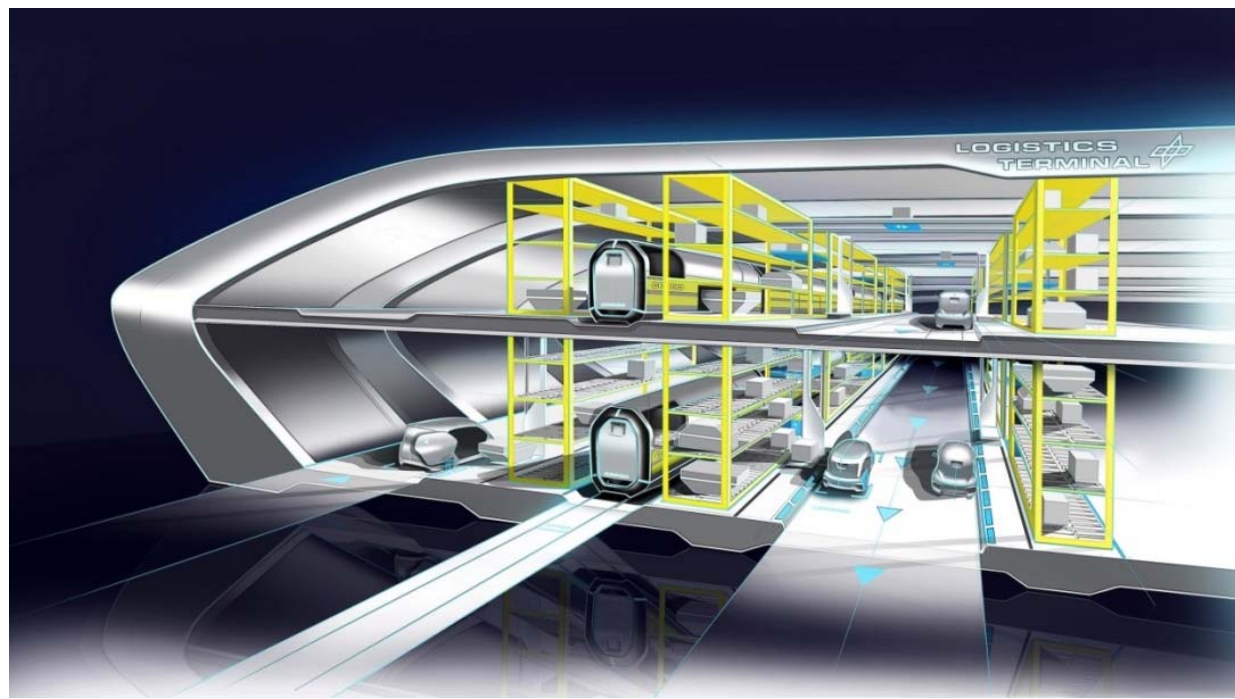

Figure 2: NGT CARGO intermodal logistics terminal. (Source: DLR.)

For high-speed operation, up to ten NGT CARGO single wagons form a unit and are integrated into the trainset with two power cars at the ends (see Fig. 3). One trainset has a length of $250 \mathrm{~m}$ and maximum weight of 816 tons. The power cars provide the main traction required for high-speed operation. The NGT CARGO can reach a speed of up to $400 \mathrm{~km} / \mathrm{h}$, if a suitable infrastructure is available. Where no high-speed lines are available, the NGT CARGO will use existing infrastructure with lower maximum speeds. The train meets the 


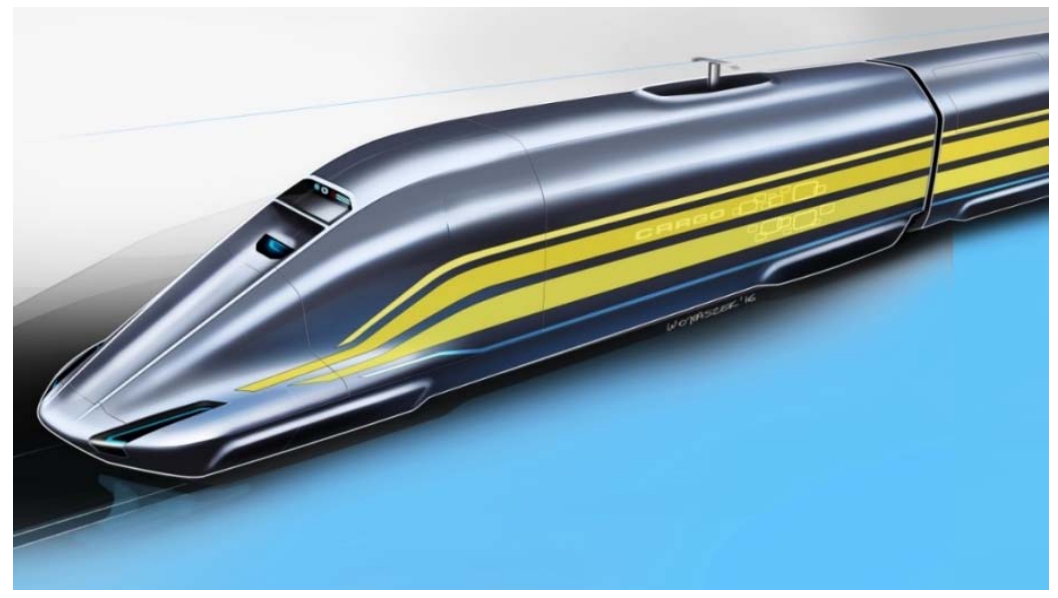

Figure 3: NGT CARGO trainset with power car. (Source: DLR.)

HGV conditions, e.g. a $17 \mathrm{t}$ axle load and an aerodynamic design. Several NGT CARGO trainsets can be virtually coupled during the journey. They form a train but are not connected by a mechanical coupling. This leads to cost savings, as no complex mechanical coupling systems have to be carried along. Three single configurations can be virtually coupled to a $750 \mathrm{~m}$ trainset. A combination with the high-speed passenger train NGT HST (high-speed train) is also possible. In this way, passenger and freight traffic are bundled in order to make optimum use of existing line capacities.

\section{CHOICE OF ADEQUATE GOODS AND A REFERENCE LINE}

Together with the DLR Institute of Transport Research (VF) we selected adequate good types which have the value to justify fast freight transport [4]. The requirements of these goods are that they are of high value, they are urgent, they have a difficult predictable traffic volume and they have to be managed carefully. The good types are classified in the traffic forecast of the German Federal Transport Infrastructure Plan (BVWP) [5], so there is a database for further calculations. As a result of the categorization the following good types are adequate for the NGT CARGO (the volume is shown in Fig. 4):

- $\quad$ Fresh fruit and vegetables

- Living plants and flowers

- Meat

- Milk, milk products, ice cream

- Clothing

- Print products, record carriers, data media

- Pharmaceutical products

- Electronic components

- Measuring instruments, clocks

- Machine parts

- Furniture

- $\quad$ Post, packages, parcels

- Consolidated cargo. 


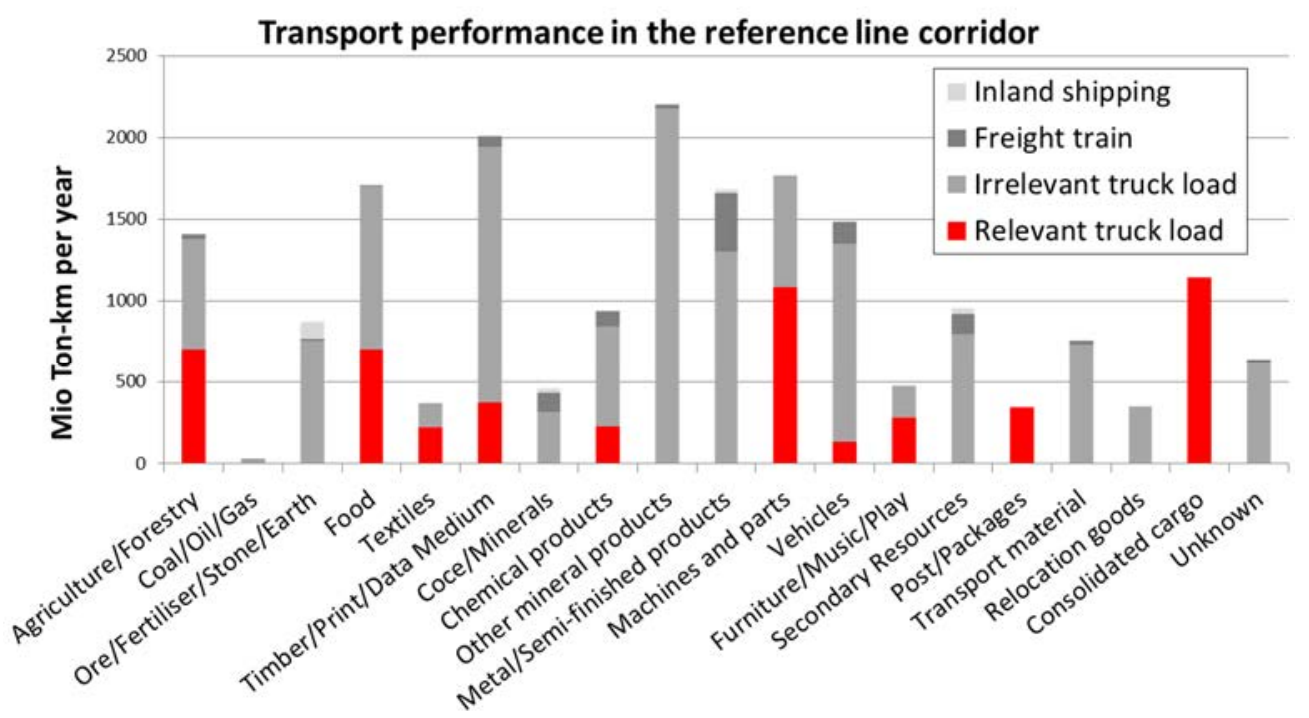

Figure 4: Total and relevant transport performance itemized by cargo type on the reference line Spain-Romania.

Two important types of cargo are excluded in the further process:

- Cars would fit the requirements, but they are too big to be loaded into the train. Furthermore, they are already rail-affine, so it is assumed, that there is no willingness to pay for a faster transport.

- ISO-Containers are also excluded from the list. Beside the fact that the size does not fit the train, there is no requirement for a fast transport, if the containers are transported by ship relatively slow. Moreover, the deadweight would increase very much as there would be the aerodynamic shell of the train and the container shell.

Due to the fact, that high-value goods are often not very heavy it is important to use an additional measurement for tons and ton kilometres. The good types are analysed regarding their stow value. An average stowage factor of $4 \mathrm{~m}^{3}$ per ton $\left(250 \mathrm{~kg} / \mathrm{m}^{3}\right.$ density $)$ is found out and used for calculating the freight volume and train occupation [6].

For the choice of a reference line important origin-destination pairs in Europe are evaluated regarding the transport volume after filtering the adequate goods. A relation is more preferable, if it has a long distance, it has symmetric transport volumes and of course a high total transport volume. The minimum distance regarded in this and every following step is $300 \mathrm{~km}$. For lower distances it is assumed, that a rail transport is not competitive to the road. The resulting relation of the analysis is Spain-Romania and vice versa. The route crosses Germany implicitly because the German Transport Forecast only contains cargo which has its origin or destination there or crosses the country. A look on the map tells the reason for this detour: The Alps are a traffic obstruction and the southern route through Italy has some disadvantages regarding travel speed and cost. 


\section{DESCRIPTION OF THE REFERENCE LINE SPAIN - ROMANIA}

The NGT CARGO will mostly use both existing high-speed lines and lines which are highly likely to be completed by 2025 to 2030 . The lines for which completion dates have been announced up to this period are selected. If no high-speed line is available, the NGT CARGO uses the existing rail network, which is electrified and has standard gauge. The line choice was influenced by the maximum achievable speeds and the predominant types of traffic on the already existing line. For example, the use of high-speed lines allows the NGT CARGO to follow fast long-distance passenger traffic without suffering constraints. The total distance of the reference line is about $3700 \mathrm{~km}$ (see Fig. 5). The reference line is created using data from various sources [7]-[10].

In Spain, the NGT CARGO starts in Madrid close to Atocha main station. After leaving Madrid, the train travels on the Madrid-Barcelona standard gauge high-speed line. This section allows a maximum speed of $310 \mathrm{~km} / \mathrm{h}$. In Barcelona the centre is crossed by using the city tunnel. The high-speed line ends shortly before Perpignan behind the border to France (maximum speed $350 \mathrm{~km} / \mathrm{h}$ ).

The NGT CARGO continues its journey in France. Due to the missing section of the highspeed line between Perpignan and Montpellier, the train uses the existing infrastructure along the Mediterranean coast $(160 \mathrm{~km} / \mathrm{h})$. In the Montpellier area, the train is changing to the highspeed line towards Avignon, which is currently under construction $(300 \mathrm{~km} / \mathrm{h})$. From Avignon junction NGT CARGO takes the busy Rhone-Alpes high-speed line $(300 \mathrm{~km} / \mathrm{h})$. Northeast of Lyon, the trainset is moving to the southeastern part of the Rhin-Rhone Sud high-speed line currently being planned. Via Bourg-en-Bresse in the Dole area, the train reaches the western axis of the Rhin-Rhone line towards Mulhouse. The section between Lyon and Dole allows a maximum speed of 220 to $270 \mathrm{~km} / \mathrm{h}$. The Western part of the RhinRhone line can be used at a speed of $320 \mathrm{~km} / \mathrm{h}$. The subsequent route towards the German border only allows a maximum speed of $90 \mathrm{~km} / \mathrm{h}$.

In Germany, the NGT CARGO arrives at the Rhine Valley Railway in the Müllheim area in the direction of Karlsruhe. The section between Müllheim, Offenburg and Karlsruhe will be mostly extended to a maximum speed of $250 \mathrm{~km} / \mathrm{h}$ in future. At Bruchsal, the NGT CARGO changes to the high-speed line Mannheim-Stuttgart $(250 \mathrm{~km} / \mathrm{h})$. At Stuttgart the

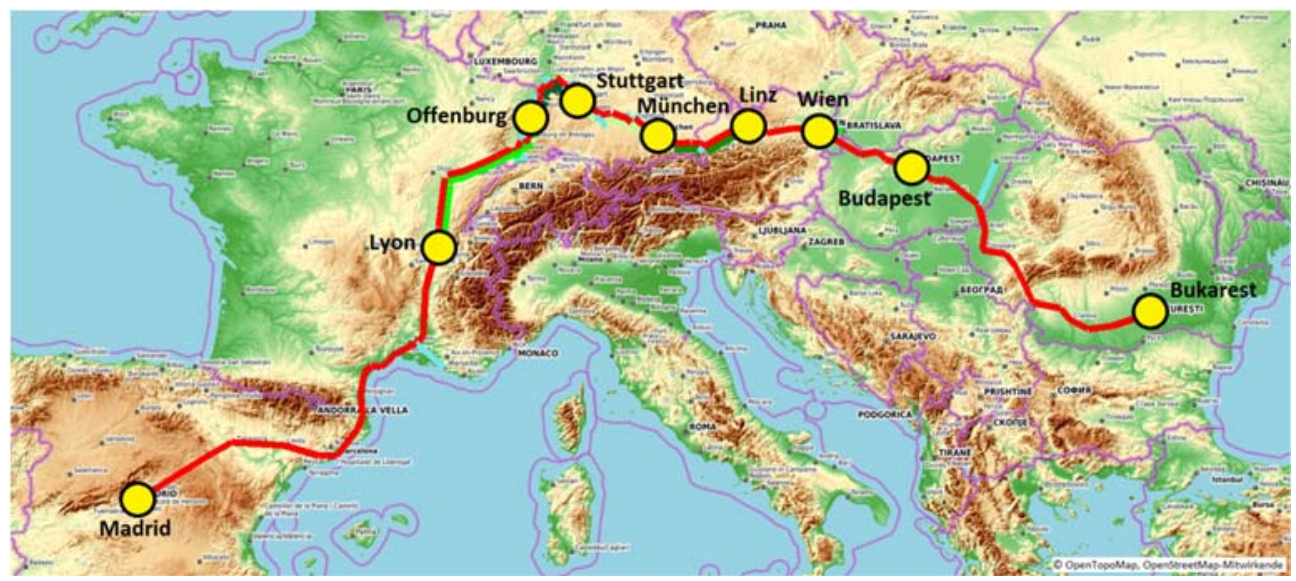

Figure 5: NGT CARGO reference line from Madrid to Bucharest. (Source: DLR, OpenTopoMap, OpenStreetMap.) 
train takes the northern freight bypass and then takes the high-speed line Wendlingen-Ulm, which is currently under construction $(250 \mathrm{~km} / \mathrm{h})$. Via Ulm and Augsburg, the train reaches Munich, where the freight rail bypass in the north is used. The route continues to Austria via Rosenheim and Salzburg (mostly slower than $160 \mathrm{~km} / \mathrm{h}$ ).

Arriving in Austria, the NGT CARGO travels from Salzburg via the Western main line in the direction of Vienna. The maximum speed varies from only around $90 \mathrm{~km} / \mathrm{h}$ in the west to 160,200 and $230 \mathrm{~km} / \mathrm{h}$ in the sections further east, where a high-performance line has been built in recent years. In the area of the Wienerwald tunnel $250 \mathrm{~km} / \mathrm{h}$ is permitted. South-east of Vienna, the route to Hungary is made via existing lines, which allow a maximum speed up to $160 \mathrm{~km} / \mathrm{h}$.

In Hungary, NGT CARGO serves Györ, Budapest and Bekescsaba. The infrastructure in Hungary allows a maximum speed of $160 \mathrm{~km} / \mathrm{h}$ for the most part. The train will be operated from the border crossing in Hegyeshalom via Györ and Tatabanya to the capital Budapest. The train travels from Budapest via Szolnok and Bekescsaba towards the Romanian border.

In Romania, the NGT CARGO will use the line from the Hungarian border via Arad to Timisoara. The train will then operate the Timisoara-Bucharest line via Drobeta-TurnuSeverin and Craiova. The maximum speed between the Hungarian border and Arad is only $120 \mathrm{~km} / \mathrm{h}$. In the section between Timisoara and Drobeta-Turnu-Severin only about $70 \mathrm{~km} / \mathrm{h}$ are allowed. The maximum speed for the following section to Rosiorii de Vede is $120 \mathrm{~km} / \mathrm{h}$, while the last part of the route to Bucharest can be used at $100 \mathrm{~km} / \mathrm{h}$.

The total travel time from Madrid to Munich is 15.5 hours and another 20.8 hours to Bucharest. This time includes 1-hour-stops in every hub.

\section{OPERATIONAL SCENARIOS}

The distribution of the freight volume is known for the defined traffic cells of the traffic forecast. These cells are on a detailed level inside of Germany and in neighbouring areas. With a larger distance from Germany the cell size rises and the accuracy decreases and - of course - the traffic volume grows. Nevertheless it is possible to figure out some stations with an outstanding traffic volume which predestines them to be a transport hub. On the one hand, there is a larger need for shunting the trains; on the other hand, also the transhipment volume is big. Looking at the transport volume data, the following stations are selected to function as a hub: Lyon, Offenburg, Stuttgart, Munich and Vienna. This definition helps to create an operational concept with express and local trains. All stations between the hubs are served by local services.

To achieve a high transport speed from the shipper to the recipient it is important, that the departure is available at a high frequency. This is similar to the regular timetable for passenger trains, which allows the use of trains nearly at the requested departure time. One day is set as the minimal departure interval from every traffic cell, which means every shipper or terminal. So there has to be a departure every 24 hours on 250 days a year. Weekend and public holidays are excluded because there is not the same industrial output as on working days. We have to keep in mind that a higher departure frequency decreases the unit volume of one departure and possible operational concepts get more complicated.

For the creation of the operational concept we define two base scenarios:

- $\quad$ Single wagon load system (E)

- Line train system (L).

Within the single wagon load system one wagon is loaded at the origin and completely unloaded at the destination. Within the line train system the goods are loaded during a stop 
of the complete train at a terminal, eventually transhipped at hubs into another train and unloaded at the destination terminal during the stop of the complete train. The latter system implies the usage of the road for the first and last mile, because the terminal position where the train stops has to be located along a main or high-speed railway to avoid travel time extensions for the whole train.

Interim stages between these scenarios are conceivable. On the one hand, a single wagon could be loaded at different terminals or sidings and completely unloaded at the destination station. On the other hand, a single wagon could be completely loaded with freight for one destination area and is unloaded at different terminals or sidings in that area.

To create an economic viable scenario there are different, partly contrary optimization targets:

- Fastest average transport time for all freight units,

- Highest average train occupancy or

- Lowest shunting or transhipment effort.

To reach one of the targets mathematical models have to be established. Due to effort reasons, this was not done, but we have calculated both of the base scenarios. This gives indications towards achievement of the targets.

The next step is the calculation of wagons per line section. The demand for the fast longdistance service stopping only at the hub stations is five times higher than for the local services (see Fig. 6). The number of (partly) loaded wagon differs in both directions, which means that there will be also empty or weakly loaded wagons moving in the trains. Due to the fact, that the German traffic forecast contains all local freight traffic in Germany, but not outside, the maximum usage occurs on the German section of the line. It is likely that there will be also freight relations in Spain and France and also in Hungary and Romania which will lead to a bigger freight volume on the whole line and a similar operational program as on the German section.

At this stage the first results show the preferable concept: The single wagon load system (E) has 253 wagons per day and direction on the strongest section, whereas the line train system (L) needs only 146 wagons transporting the same freight volume. The operating performance for scenario $\mathrm{E}$ is $44,000 \mathrm{~km}$ and for scenario L 33,000 km. The average freight space occupation is much better for the scenario L with $79 \%$ whereas scenario $\mathrm{E}$ has only $53 \%$.
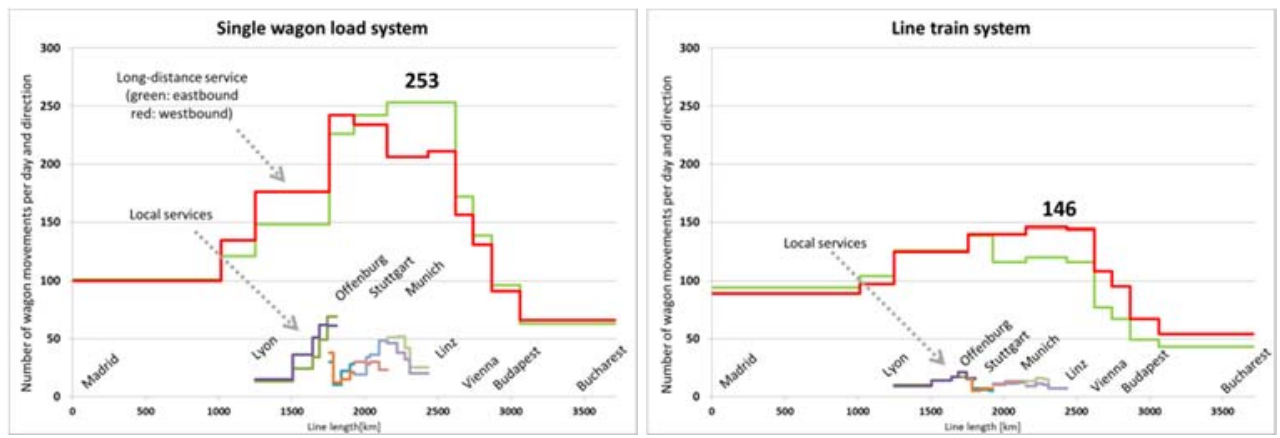

Figure 6: Number of (partly) loaded wagons along the route for single wagon load system (E) and line train system (L). 
Because the line train system is much more efficient, the detailed timetable creation is only done for this scenario. 100 wagons a day have to be transported from Spain to France. One 750-m-trainset contains 30 wagons. Therefore at least four trains per day and direction have to depart. This leads to a six-hour-interval of the long-distance line, which is condensed in the central parts of the route. The whole line is travelled within one and a half day. Most of the local lines run twice a day. On the first run in the morning goods could be delivered and on the second run in the evening goods could be collected.

\section{TIMETABLE INTEGRATION}

When integrating the NGT CARGO journeys into the timetable, it is an important assumption that all passenger trains still have the highest priority and should not be modified regarding timetable and travel time. The data for the passenger train timetable and data about the number of freight trains is gathered from different sources [11]-[14].

The high speed of the NGT CARGO makes it possible to adapt to passenger traffic on high-speed and upgraded lines. Free Capacity on most high-speed passenger traffic lines allows the usage of the preferred train path. On Spanish, French and German high-speed lines, it is no problem to find a train path for the NGT CARGO. It does not obstruct any other fast passenger trains.

Challenges for train path allocation exist on mixed traffic lines with fast long-distance passenger traffic and slow commuter trains. Difficulties arise where the NGT CARGO has to share the tracks with commuter trains. The speed differences are huge and additional overhauls cannot be realized without major damage to the regular timetable of the commuter traffic due to the short travel and connection times. Conflicts can be resolved by reducing the speed of the NGT CARGO, resulting in a slight increase in travel time.

Mixed traffic with the much slower conventional freight trains causes minor problems, as the NGT CARGO overtakes them like a fast passenger train. In return, this means longer waiting times and obstructions for conventional freight trains.

On some routes with dense mixed traffic (such as the Munich-Rosenheim line) the speed level is lower than on upgraded lines like the Rhine Valley Railway. On the MunichRosenheim line the NGT CARGO cannot overtake other trains. Therefore, there are no problems to find train paths for the NGT CARGO, despite the fact that this line can be classified nearly as a bottleneck. However, the NGT CARGO would be slightly faster if the line would be less congested.

Taking everything into account, the timetable integration of the NGT CARGO shows that it is easy to find routes on the high-speed lines. Problems arise on the mixed traffic routes, especially when there is a mixture of long-distance and commuter trains. On routes with dense freight traffic, but lower speeds, the harmonious speed level makes it easier to find train paths for the NGT CARGO.

\section{RESULTS AND CONCLUSION}

A line train system achieves a clearly better train occupation than a single wagon load system. The reason is that due to the high departure frequency the freight volume gets very small and should be consolidated to achieve better cargo space usage. Keeping in mind, that not the whole truck freight volume will be shifted to rail, the problem gets even worse. Thus, it is necessary to integrate procedures of consolidating cargo and nevertheless keeping the average transport speed high. The average occupation of the single wagon load system (E) is $53 \%$, whereas the line train system (L) achieves $79 \%$.

The average transport speed for one load unit, which could be a euro pallet or an air cargo container, is $67.5 \mathrm{~km} / \mathrm{h}$ in the L-scenario (average transport time 18 hours) and is only just 
below the value of the ideal timetable. That ideal timetable ignores other train traffic on the line. The integration into the timetable is unproblematic on high-speed lines, but challenging on mixed-traffic lines with fast and high-speed passenger trains. To compare the results with classic technology, an express container train capable of riding $160 \mathrm{~km} / \mathrm{h}$ is simulated. The average transport speed of this train is $38.8 \mathrm{~km} / \mathrm{h}$ ( 29 hours). A complete road transport achieves $33.3 \mathrm{~km} / \mathrm{h}$ (44 hours) if the driver follows the regular driving period of no longer than 10 hours a day. With autonomous truck transport the breaks can be skipped - this would lead to a very competitive speed of $55.2 \mathrm{~km} / \mathrm{h}$. But this value is only achieved by direct connections. Even the truck traffic has to consolidate the cargo which leads to detours and transhipment times which reduce the speed.

The specific energy consumption in the L-scenario is $49.7 \mathrm{kWh} / \mathrm{km}$. Within the integrated timetable it achieves a lower value of $45.3 \mathrm{kWh} / \mathrm{km}$ due to less speed peaks and a slightly lower average speed. The $160-\mathrm{km} / \mathrm{h}$-container train takes $26.9 \mathrm{kWh} / \mathrm{km}$, which is $40 \%$ less.

The number of necessary power cars or locomotives is around 110 in the L-scenario and 43 with the classic container train. For the latter an additional banking engine is necessary on the new Stuttgart-Ulm line due to the steep ascent. The number of wagons is 520 in the Lscenario and due to the lower speed 610 wagons with the $160-\mathrm{km} / \mathrm{h}$-train.

Thus, the line train scenario is the preferred one. It is necessary to create an efficient and economic viable transhipment terminal system. Ideally, the transhipment shall be work automatically. The pallets or small containers have to be moved automatically inside the wagon to the doors, between the train and terminal and inside the terminal between the train's door position and storage spaces or other train's door position.

The operation of sidings close to the manufacturer or the recipient is preferable if the cargo volume is big enough to allow a high departure or arrival frequency. In other cases road feeder services have to be used. This will also be relevant, because the origin and destination of freight which will be shifted to rail is not connected to the rail network in most cases.

\section{REFERENCES}

[1] Winter, J., Krüger, D., Böhm, M., Mönsters, M. \& Schumann, T., NGT CARGO - Ein Betriebskonzept für den internationalen Güterverkehr, Bahn Fachverlag Berlin, Deine Bahn, pp. 12-16, Aug. 2017.

[2] FIS, Forschungsinformationssystem, Information about segments of rail freight transport. www.forschungsinformationssystem.de. Accessed on: 7 Aug. 2018.

[3] Krüger, D., Malzacher, G., Böhm, M. \& Winter, J., NGT CARGO - An intelligent rail freight system for the future. European Transport Conference, Barcelona, Spain, 2017.

[4] Knitschky, G., Lobig, A., Schumann, T. \& Mönsters, M., Marktanalyse und Betriebskonzept für den Next Generation Cargo, EI - Der Eisenbahn-Ingenieur, issue 3/2018, DVV Media Group GmbH: Hamburg, pp. 40-45, 2018.

[5] BVU, ITP, IVV, PLANCO, Verkehrsverflechtungsprognose 2030, Schlussbericht, 11. Juni 2014 (Traffic Forecast 2030), commissioned by German Federal Ministry of Transport (BMVI), 2014.

[6] TIS GDV, Transport Information Service by General Association of German Insurers (GDV). www.tis-gdv.de. Accessed on: 6 Dec. 2016.

[7] OpenRailwayMap.org, free railway map, railway layer for OpenStreetMap (OSM) with infrastructure and speed information. https://www.openrailwaymap.org/. Accessed on: 2016 and 2017.

[8] Wikipedia, free encyclopedia, used for collecting information about railway tracks like kilometrage, stations or linking with other routes. https://en.wikipedia.org. 
[9] Schweers, H. et al., Eisenbahnatlas Deutschland, 10th ed., Schweers and Wall: Köln, 2017.

[10] Schweers, H. \& Wall, H., Eisenbahnatlas EU, 2nd ed., Schweers and Wall: Köln, Germany, 2013.

[11] German Federal Ministry of Transport and Digital Infrastructure (Bundesministerium für Verkehr und digitale Infrastruktur BMVI), SMA und Partner AG, Zielfahrplan 2030 zum BVWP 2030, Fernverkehr, 18 Jun. 2017.

[12] Potter, J.C. et al., European Rail Timetable: Summer 2016 Edition, European Rail Timetable Limited: UK, 2016.

[13] German Federal Railway (Deutsche Bahn) timetable information, reiseauskunft.bahn.de based on HaCon Fahrplan-Auskunfts-System (HAFAS), access for 2016 and 2017 timetable in Germany.

[14] Holzhey, M., Schienennetz 2025/2030 - Ausbaukonzeption für einen leistungsfähigen Schienengüterverkehr in Deutschland, Rail network 2025/2030 - Expansion concept for an efficient rail freight service in Germany, German Federal Environment Agency (Umweltbundesamt UBA), 2010, English summary. https://www.umweltbundesamt. de/sites/default/files/medien/461/publikationen/4005-0.pdf. 